Scientific Journal Warsaw University of Life Sciences - SGGW

Problems of World Agriculture volume 19 (XXXIV), number 1, 2019: 180-191

DOI: 10.22630/PRS.2019.19.1.17

Kaja Karwowska $^{1}$, Magdalena Skotnicka ${ }^{2}$, Maria Śmiechowska ${ }^{3}$

${ }^{1,2}$ Medical University of Gdańsk, Poland

${ }^{3}$ Gdynia Maritime University, Poland

\title{
Tea Production and its Forecasts, and the Possibility of Tea Cultivation in the Context of Environmental Requirements in China
}

\begin{abstract}
The present study demonstrates the reasons for the foundation of tea plantations and conditions of their cultivation. The limitations and negative consequences of cultivation of tea plants along with the ideas for their minimization are shown. Plantations were created to optimize the harvest. However, it has been found that they negatively influence local ecosystems. The global demand for tea leaves is constantly growing. Due to the specific climate requirements of tea plants and progressive climate changes, the arable land area suitable for their cultivation is constantly decreasing. New solutions should be implemented as soon as possible, ensuring a constant supply of raw material. Otherwise, in the next few years tea may become a luxury product. FAO has presented the activities that could reduce the losses. At the moment, the best solution might be to change crop types and diversify sources of raw material. It is also highlighted that there is a need to carry out research aiming at developing varieties of Camella sinensis with lower climate requirements.
\end{abstract}

Key words: tea, plantations, crop types, climate changes, local ecosystems

JEL Classification: Q11, Q15

\section{Introduction}

Tea is currently one of the most popular drinks consumed worldwide. Its assortment is very rich - teabags or leaf teas, flavored and non-flavored, belonging to different species and types and originating from many countries. Such diversification means that the consumer has a wide range of choices and can adapt the product to his or her preferences. Interestingly, all kinds of teas - according to the Chinese classification, there are as many as six (white, yellow, green, oolong, red, and black) - are obtained from plants of the same species (Wachira et al., 2013, Tomczyk, 2009).

The first documented information about tea comes from the turn of the seventh and sixth centuries BC. Initially, it was used as a medicinal plant, mainly in the case of stomach ailments. Literature lacks information on when exactly tea became a drink. It is known, however, that initially drinking tea was reserved for the imperial family. In 705 , thanks to the monk Dengyo Daishi, tea reached Japan. In a similar period, it also appeared in Tibet. The period from the 10th to the 13th century was instrumental to the development of the tea

\footnotetext{
${ }^{1}$ MSc Eng., Department of Food Commodity Science Medical University of Gdańsk, Dębinki 7, 80-211 Gdańsk, e-mail: kajakarwowska@gumed.edu.pl; https://orcid.org/0000-0001-7359-2164

${ }^{2}$ PhD Eng., Department of Food Commodity Science Medical University of Gdańsk, Dębinki 7, 80-211 Gdańsk, e-mail: magdalena.skotnicka@gumed.edu.pl; https://orcid.org/0000-0002-0853-0685

${ }^{3}$ Professor, PhD, Department of Commodity Science and Quality Management, Gdynia Maritime University, Morska 81-87, 81-225 Gdynia, e-mail: m.smiechowska@wpit.am.gdynia.pl; https://orcid.org/0000-0001-6933-594X
} 
culture, when numerous teahouses were formed, the habit of drinking tea spread to various social classes and aromatizing tea began. In the nineteenth century there was a rapid growth of the tea market. The habit of drinking tea spread both in Europe and Asia, which increased the demand for this raw material on a global scale. Production in China was unable to cover the demand of the global market, therefore new areas for cultivation and an efficient cultivation system were needed to maximize the quantity of raw material obtained. This situation meant that commercial crops were gradually extended to Sri Lanka, Indonesia and India, and then to English colonies in Africa (Ahmed and Stepp, 2013a, Krzyżanowski, 2008, Tomczyk, 2009, Toyb, 2016). The solution, which was supposed to provide more raw material obtained from the same crop area, is a well-known and applied plantation system.

The aim of this study is to indicate the reasons for the emergence of plantations of tea plants, the conditions of their management and their advantages, disadvantages and limitations. The final part of the work presents solutions that can be an alternative to plantation crops and that can reduce the waste of raw materials resulting from the progression of climate change. The goal will be implemented through a literature review.

\section{Tea - production, import, consumption}

Currently, the tea plant is grown in over 30 countries, mainly in Asia, Africa and South America. Small amounts also come from North America, Australia and Europe (Toyb, 2016). The total global area of tea plantations in 2014 was 3,800,000 ha, of which more than $50 \%$ were located in China (Table 1). In the same year, the tea harvest was estimated at a combined amount of 5561 thousand tonnes. Almost $78 \%$ of the raw material was obtained from crops located on the Asian continent - the highest in China (2096 thousand tonnes) and India (1207 thousand tonnes) (GUS, 2017a, GUS, 2017b). For many years, tea production has been dominated by the same countries, namely China, India, Kenya, Sri Lanka and Turkey. In total, Asian countries produced over 4.7 million tons of tea in 2014 , which accounted for $85 \%$ of world production. In turn, annual tea production in African countries at that time amounted to slightly more than 744,000 tons, which constituted only $13 \%$ of global production. According to FAO (Food and Agriculture Organization of United Nations), in 2016, 5.73 million tons of tea was obtained. This value maintains a constantly growing trend (FAO, 2018c). Countries that excel in the size of crops, harvesting and final production of tea are characterized by some of the lowest yields of tea bushes (China - 2005: $9.0 \mathrm{dt} \cdot \mathrm{ha}^{-1}, 2013: 11.0 \mathrm{dt} \cdot \mathrm{ha}^{-1}$; India - 2010: $17.1 \mathrm{dt} \cdot \mathrm{ha}^{-1}, 2013$ : $\left.21.4 \mathrm{dt} \cdot \mathrm{ha}^{-1}\right)$. The highest yields are recorded in Iran (2010: $\left.85.1 \mathrm{dt} \cdot \mathrm{ha}^{-1}, 2013: 65.3 \mathrm{dt} \cdot \mathrm{ha}^{-1}\right)$ and Burundi (2011: $48.4 \mathrm{dt} \cdot \mathrm{ha}^{-1}, 2013: 45.8 \mathrm{dt} \cdot \mathrm{ha}^{-1}$ ). This is mainly due to the prevailing climatic conditions and the frequency of harvesting (e.g., China and Japan 3-5 times a year, India and Indonesia up to 15 times a year) and climate change. The largest tea importers in 2016 were the countries of the European Union (18\%), Russia (9\%), Pakistan (9\%), the United States (7\%) and Egypt (5\%). These quantities indicate that the main recipients of the product are its producers. In 2016, global tea consumption increased by $4.5 \%$ compared to the previous year and amounted to 5.53 million tonnes.

The steady increase in consumption for years has been associated with population growth, urbanization and growing incomes, especially in emerging and developing economies. In Poland, in the years 2012-2016, the volume of imports was at a similar level. Initially, it was 
32.9 thousand tonnes, and in 2016 it reached 35.6 thousand tonnes, eventually reaching PLN 418.9 million. During the same period, the average monthly consumption in Poland, per one person, remained at a constant level of $0.06 \mathrm{~kg}$ of dried tea. It was only in 2016 that it fell slightly to $0.05 \mathrm{~kg}$. The largest quantities of dried tea are consumed by the inhabitants of Turkey (about $4.0 \mathrm{~kg}$ per person per year), Libya (about $2.25 \mathrm{~kg}$ per person per year), Morocco (about $1.85 \mathrm{~kg}$ per person per year), Ireland (about $1.7 \mathrm{~kg}$ per person per year), Great Britain (about 1.7 $\mathrm{kg}$ per person per year) and Hong Kong (about $1.55 \mathrm{~kg}$ per person per year). One of the factors that inhibit the growth of tea consumption in Poland is definitely its price. While on the global markets from 2012 to 2016 a drop to USD 2.57 was recorded for $1 \mathrm{~kg}$ of black tea (Figure 1), in Poland since 2010 there has been a steady price increase. The decline in world markets was caused by the weakening of the economic growth rate related to lower oil prices. However, the following year, the price of tea in the global market increased by as much as $22.6 \%$, reaching a record level of USD 3.15. In Poland, in 2017, PLN 4.28 was to be paid for $100 \mathrm{~g}$ of black tea (FAO, 2018b, FAO, 2018c, GUS, 2013b, GUS, 2014, GUS, 2015b, GUS, 2016, GUS, 2017a).

Table 1. Selected quantities related to the cultivation and production of tea in 2005-2014

\begin{tabular}{|c|c|c|c|c|c|c|}
\hline $\begin{array}{c}\text { Selected } \\
\text { territories }\end{array}$ & 2005 & 2010 & 2011 & 2012 & 2013 & 2014 \\
\hline \multicolumn{7}{|c|}{ Plantation area (thousand ha) } \\
\hline world & b.d. & 3118 & 3244 & 3276 & 3521 & 3800 \\
\hline China & b.d. & 1420 & 1500 & 1500 & 1750 & 1984 \\
\hline India & b.d. & 583 & 580 & 605 & 564 & 604 \\
\hline Sri Lanka & b.d. & 218 & 222 & 222 & 222 & 222 \\
\hline Kenya & b.d. & 172 & 188 & 191 & 199 & 203 \\
\hline \multicolumn{7}{|c|}{ Tea harvest (thousand tonnes) } \\
\hline world & 3682 & 4604 & 4668 & 4818 & 5346 & 5561 \\
\hline China & 935 & 1450 & 1623 & 1700 & 1924 & 2096 \\
\hline India & 907 & 991 & 967 & 1000 & 1209 & 1207 \\
\hline \multicolumn{7}{|c|}{ Yield (from 1 ha in dt) } \\
\hline world & 13,7 & 14,6 & 14,0 & 14,3 & 15,2 & b.d. \\
\hline Iran & 17,4 & 85,1 & 43,4 & 65,8 & 65,3 & b.d. \\
\hline Burundi & 44,5 & 46,1 & 48,4 & 40,1 & 45,8 & b.d. \\
\hline Thailand & 33,7 & 34,6 & 36,3 & 35,2 & 34,9 & b.d. \\
\hline India & 17,4 & 17,1 & 18,3 & 18,8 & 21,4 & b.d. \\
\hline China & 9,0 & 10,2 & 9,9 & 10,3 & 11,0 & b.d. \\
\hline \multicolumn{7}{|c|}{ Tea production (thousand tonnes) } \\
\hline world & 3014 & 4603 & 4773 & 5034 & 5349 & 5561 \\
\hline Asia & 2476 & 3826 & 4032 & 4299 & 4541 & 4717 \\
\hline Africa & 438 & 666 & 631 & 637 & 712 & 743 \\
\hline
\end{tabular}

Source: Authors' own elaboration based on GUS data (Rocznik Statystyki Międzynarodowej: 2012, 2015, 2017; Rocznik Statystyczny Rzeczpospolitej Polskiej: 2013, 2014, 2015, 2016, 2017). 


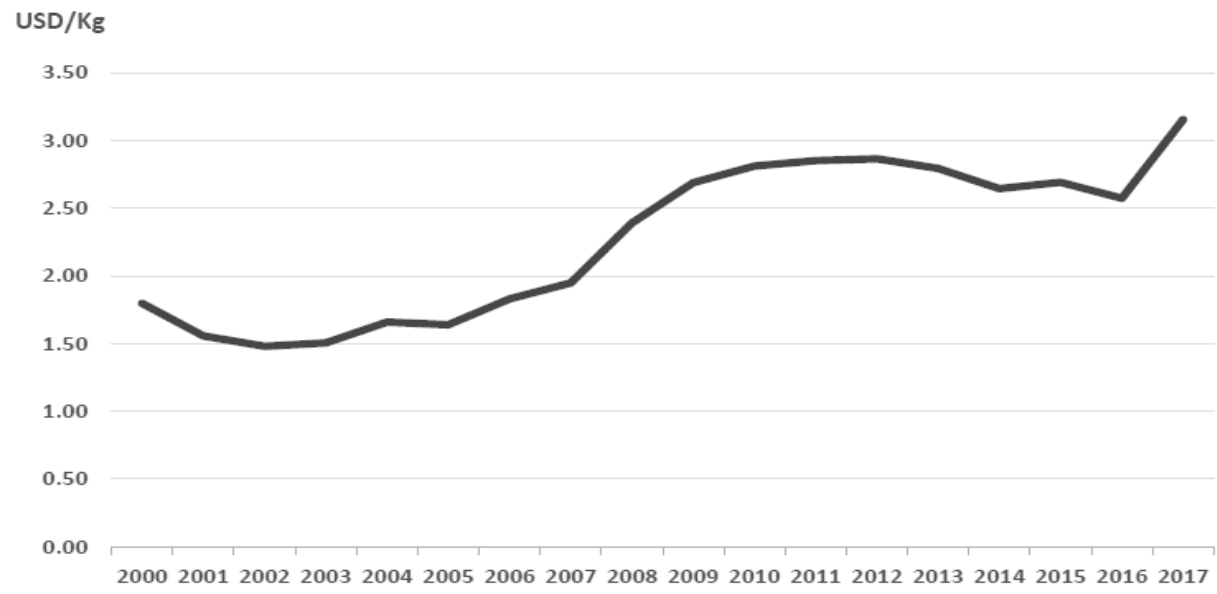

Fig. 1. Orientational black tea price changes in the world in 2000-2017

Source: FAO (2018c).

Forecasts for 2027 predict that the production volume of black tea will grow steadily by $2.2 \%$ per year and will finally reach 4.42 million tonnes. The largest increases are expected for China, Kenya and Sri Lanka. For green teas, an even faster growth is expected, $7.5 \%$ each year up to 3.31 million tonnes in 2027. The largest increase is forecast for China, which will double the value from 2017. The Intergovernmental Group on Tea, operating at the FAO, states that changes in the production volume will not be related to the increase of arable land and increased productivity. Experts predict that tea consumption in the world will also grow $2.5 \%$ per annum and in 2027 will reach 4.17 million tonnes. The largest increases will be recorded by the current leaders of tea production, and the smallest by the countries of Western Europe, where the market of coffee and other beverages is dynamically developing (FAO, 2018a). The presented forecasts take into account the current trends prevailing on global markets and the current losses in the raw material. However, this problem will deepen with the ongoing climate change. The improvement of crop efficiency is theoretically possible, as shown in Table 1 . However, applying the currently used methods, raw material losses will not be limited. There are no simulation models to predict the exact change in yields due to climate change. Due to the limited areas suitable for tea, progressive climate changes and destruction of local ecosystems through intensive cultivation, new solutions should be sought. Cultivations that are environmentally friendly and reduce the losses of raw material should be sought, which will enable global demand to be met and will not lead to a situation where tea will become a luxury product.

\section{Plantation cultivations of tea}

The cultivation of tea requires strictly defined climatic and soil conditions. Different varieties of the same species have slightly dfferent requirements. Camellia sinensis var. sinensis grows in cooler mountainous regions, while Camellia sinensis var. assamica grows best in a tropical climate. Nevertheless, it is considered that optimal cultivation conditions 
are annual precipitation at the level of $2500-3000 \mathrm{~mm}^{3}$ per square meter, temperature in the range $18-20{ }^{\circ} \mathrm{C}$ and the location of plots at heights up to $2,200 \mathrm{~m}$. However, some crops are carried out in areas where the annual rainfall amounts to $1200-1500 \mathrm{~mm}^{3}$ per square meter and the temperature does not drop below $12{ }^{\circ} \mathrm{C}$ and does not exceed $30^{\circ} \mathrm{C}$. For some types of teas, it is desirable to cultivate at altitudes up to $3000 \mathrm{~m}$. For growth, the plant needs at least 5 hours a day of direct sunlight or 11 hours of scattered light. The soil must be permeable, airy, with a low $\mathrm{pH}(4.5-5)$ and with a fertile humus layer. The cultivation of these plants is increasingly carried out under controlled conditions that guarantee obtaining the raw material of proper quality. Unfavorable conditions, such as droughts, floods, frosts or excessive heat, limit plant growth and lead to changes in the biochemical structure of the raw material, which lead to a decrease in its quality (Ahmed and Stepp, 2013a; Ahmed and Stepp, 2013b; Kumar et al., 2013). The quality of tea depends primarily on the quality of the raw material, which is determined by the variety of the plant, climatic and soil conditions, the altitude of the plantation, and the applied agronomic practices.

Methods of growing and harvesting tea have changed over the centuries. The emergence of the first cultivation systems dates back more than 1,700 years ago. Thanks to the scientific evidence currently available, standard guidelines for cultivating tea plants have been developed, which are used all over the world.

For the production of young bushes, seeds obtained from the plants after only 3 years of cultivation can be used. Careful care of young bushes is carried out in "nurseries" for a maximum of one year. However, seedlings (diaspora clones) are more often used, characterized by high resistance to stress and high productivity potential. Young plants are placed in the ground in rows at a distance of 1-1.5 meters from each other. When the plant reaches a height of half a meter, it is cut to a height of about $23 \mathrm{~cm}$ to stimulate lateral growth. Bushes are regularly cut to a height of about $1-1.2 \mathrm{~m}$ in such a way as to give them a rectangular shape, called a "table". Such a method of forming plants facilitates and accelerates harvesting and ensures maximizing obtained yields. The first batch of material is obtained from two- to three-year-old plants. Tea leaves can be harvested by hand or using a machine. Automatic collection is a faster process, but is very inaccurate. The leaves can be damaged, and in the final harvest there will be a large number of stems. Good quality leafy teas always require manual harvesting.

When growing tea, the harvest is the most labor-intensive and costly process, requiring the employment of a large number of workers. According to some sources, one collector is able to collect up to $30 \mathrm{~kg}$ of fresh leaves per day. About $2.5 \mathrm{~kg}$ of dried tea is obtained from $10 \mathrm{~kg}$ of green leaves. The tea bush is used for approximately 40 years. Of course, the plant can live up to hundreds of years, but with age the amount of raw material produced by it decreases. Tea plants have many naturally occurring pests, including the beetle Xyleborus fornicatus, the red spider Oligonychus coffeae, and various kinds of larvae and mites Typhlodromus and Phytoseius. In rare cases, it is even desirable to infest the plants with a specific group of pests, but the vast majority of farmers must fight them with plant protection products (Ahmed and Stepp, 2013a; Ahmed and Stepp, 2013b; Toyb, 2016).

The purpose of plantation crops is to obtain large amounts of raw material per unit surface. This requires the development of an individual way of planting plants for each monoculture, adapted to the terrain, as well as their proper care, so that in each harvesting period maximum yield from the plantation can be obtained. In the case of tea bushes, the best results were obtained for long rows with minimal paths between them (for ease of movement), strictly defined method of pruning plants, regular harvesting and application of 
appropriate plant protection. In the case of large plantations, all work is carried out on a large scale.

Tea production is geographically limited to several areas of the world and is very sensitive to changes in growing conditions. The increasing demand for tea requires finding new growing areas. The choice of terrain is hampered by the climatic and soil requirements that must be met for the optimal growth of tea bushes. Finding a place with the right temperature, high humidity and length of the day, and the optimal altitude, significantly limits the potential area for tea cultivation. The establishment of new plantations usually begins in forested areas. Huge forests are cut out, which results in a significant loss of biodiversity. The south-western part of China is considered as virgin land, where fauna and flora are characteristic for these areas. International projects concerning environmental protection strengthen this picture. Several natural sites have been inscribed on the UNESCO world heritage list, including the protected area of three parallel rivers (Yangtze, Mekong and Saluin) in the Yunnan province. It has been described as one of the least disturbed ecological areas in the world, the epicenter of Chinese endemic species, being a natural gene pool with a great wealth of biodiversity (Hung, 2013). For this reason, these areas are advertised and perceived as a global nature reserve. Although tea plantations are associated with the traditional image of China, they constitute an artificial creation, created to cover the global demand for tea. The creation of such places livened up the local economy. However, due to intensive production, not only the country's authorities (especially at the local level), but also its inhabitants have perceived the need for change for several years: change towards modernity, associated with pro-ecological solutions.

The removal of native vegetation and the establishment of monocultures creates favorable conditions for the proliferation of pests. The severity and distribution of pests, diseases and weeds will be enhanced by the increasing temperature. Farmers will be forced to use larger amounts of pesticides, which will consequently affect food safety associated with residues of these agents in tea products (FAO, 2016). In 2008, it was reported that about $17 \mathrm{~kg}$ of pesticides were used per one hectare of crops (Gurusubramanian et al., 2008). At present, these sizes are certainly bigger and will grow steadily. Nevertheless, reports have been available for several years indicating the presence of pesticide residues in the final product. In the vast majority of cases, the quantities detected do not exceed the recommended standards and do not pose an immediate threat (Table 2). However, in the case of regular consumption of products containing even small amounts, they may accumulate in the human body (lipophilic substances) and as a consequence may lead to the development of various types of cancer (including colon, pancreas or leukemia), damage to the nervous system (e.g., Parkinson's disease, dementia and Alzheimer's disease, amyotrophic lateral sclerosis), immune or hormonal system (Greenpeace, 2015).

Tea is a perennial plant, which is why it needs regular replenishment of nutrients in the soil. High-yield varieties require more fertilizers. It is reported that high yield shrubs should receive about $100 \mathrm{~kg}$ of nutrients per 1 ha of crop (45-60 kg of nitrogen, 20-30 kg of potassium, 4-7 kg of phosphorus and $4 \mathrm{~kg}$ of calcium) in the season (Mukhopahyay and Mondal, 2017). Pesticides and fertilizers cause degradation of the biological life of the soil (e.g., acidification) and pollute the water. This is particularly harmful to the biological life of the region, including the inhabitants themselves. Limited access to running water forces the population to use wells penetrated by polluted groundwater. The long-term maintenance of plantations located on mountain slopes leads to soil erosion and to numerous landslides, which is a real threat to farms located near such crops. At the moment of closing the 


\section{K. Karwowska, M. Skotnicka, M. Śmiechowska}

plantation, the abandoned area is barren and is not suitable for other crops or the establishment of a forest. It takes many years and large resources to re-develop such an area (Toyb, 2016).

Table 2. Notifications from RASFF system in 2016-2018

\begin{tabular}{|c|c|c|c|c|}
\hline $\begin{array}{l}\text { Country of } \\
\text { origin }\end{array}$ & $\begin{array}{l}\text { Type } \\
\text { of tea }\end{array}$ & Risk decision & $\begin{array}{c}\text { Number of } \\
\text { notifications }\end{array}$ & Subject of notification \\
\hline \multicolumn{5}{|c|}{2016} \\
\hline \multirow{3}{*}{ China } & black & undecided & 1 & anthraquinone \\
\hline & Pu-erh & undecided & 1 & anthraquinone \\
\hline & green & undecided & 6 & $\begin{array}{l}\text { anthraquinone, carbendazim, imidacloprid, tolfenpyrad, } \\
\text { triazophos }\end{array}$ \\
\hline Hongkong & Pu-erh & undecided & 1 & Bacillus cereus \\
\hline \multirow{2}{*}{ India } & black & undecided & 3 & propargite \\
\hline & green & undecided & 6 & propargite \\
\hline Japan & green & undecided & 2 & dinotefuran, tebuconazole \\
\hline Marocco & Pu-erh & undecided & 1 & anthraquinone \\
\hline \multirow{2}{*}{ Taiwan } & black & undecided & 1 & dinotefuran \\
\hline & green & undecided & 1 & dinotefuran \\
\hline \multicolumn{5}{|c|}{2017} \\
\hline Brazil & no data & not serious & 1 & anthraquinone \\
\hline \multirow{2}{*}{ China } & white & undecided & 1 & acetamiprid, isoprocarb, tolfenpyrad \\
\hline & green & undecided & 6 & $\begin{array}{l}\text { acetamiprid, anthraquinone, buprofezin, dinotefuran, } \\
\text { imidacloprid, isocarbophos, tolfenpyrad, triazophos }\end{array}$ \\
\hline India & black & undecided & 2 & anthraquinone, propargite \\
\hline Japan & green & undecided & 1 & dinotefuran \\
\hline Marocco & green & undecided & 1 & anthraquinone \\
\hline \multicolumn{5}{|c|}{2018 (to October) } \\
\hline \multirow{5}{*}{ China } & no data & undecided & 3 & anthraquinone, diafenthiuron, tolfenpyrad \\
\hline & white & undecided & 1 & $\begin{array}{l}\text { acetamiprid, buprofezin, chlorpyrifos, diafenthiuron, } \\
\text { imidacloprid, tolfenpyrad }\end{array}$ \\
\hline & black & undecided & 2 & acetamiprid, dinotefuran, tolfenpyrad \\
\hline & green & undecided & 5 & $\begin{array}{l}\text { acetamiprid, anthraquinone, buprofezin, chlorpyrifos, } \\
\text { dinotefuran, pyridaben, tolfenpyrad, triazophos }\end{array}$ \\
\hline & green & serious & 1 & aluminium \\
\hline Japan & green & undecided & 4 & dinotefuran \\
\hline Marocco & green & undecided & 1 & anthraquinone \\
\hline Sri Lanka & no data & undecided & 1 & tolfenpyrad \\
\hline \multirow[t]{2}{*}{ Vietnam } & black & undecided & 4 & $\begin{array}{c}\text { acetamiprid, dinotefuran, etofenprox, imidacloprid, } \\
\text { tolfenpyrad }\end{array}$ \\
\hline & green & undecided & 1 & diafenthiuron, permethrin, tolfenpyrad \\
\hline
\end{tabular}

Source: Authors' own elaboration based on RASFF (Rapid Alert System of Food and Feed) data. 
In recent years, the negative impact of climate change on tea production has been underlined. Most tea-producing countries do not have irrigation systems and must rely only on the prevailing climatic conditions. These crops are therefore particularly vulnerable to drought and intense rainfall. Research carried out in various regions of China has shown that over the past 50 years the average annual temperature has increased. The maximum annual and maximum monthly parameters remained unchanged, but the minimum temperatures increased (FAO, 2016). Although the annual amount of rainfall increased slightly, the number of rainy days decreased by up to 13 days. In addition, the monsoon time has changed and was delayed by more than 20 days in 2011, compared to 1980. An important requirement, the humidity, also changed. During the analyzed 50 years, it decreased by almost $10 \%$. The last factor, the duration of insolation, has also not been left unchanged. It was significantly shortened from $207.1 \mathrm{~h}$ in 1950 to $158.0 \mathrm{~h}$ in 2010 . The cultivated land was affected several times by long droughts, which led to the destruction of many crops. Higher temperatures favor the development of pests that spread quickly and appear in places where they previously did not cause economic losses. The climate is currently unstable, and the tea bushes like constant and specific conditions. Both droughts and floods destroy plants. In Zhejiang province, farmers have been suffering from late spring frosts since 2003. As a result, 2008 saw losses of 988 million yuan. In the case of early varieties, spring harvest did not take place at all, which resulted in losses of 1.69 trillion yuan (FAO, 2016). The problem will intensify, so that the amount of raw material for tea production will gradually decrease. This will result in higher prices and later product range restrictions.

In order to limit losses in the production of raw tea material, the FAO report (2016) contains recommendations for tea growers (including planting bushes more resistant to climate change, protection of soil against rainwater accumulation, improvement of organic matter content in soil, irrigation during long periods of drought, nature and biodiversity protection), for local institutions (including research on varieties with better tolerance to frost and droughts, development of new crop methods, assessment of the impact of climate change on raw material production) and for national and international decision makers (including strengthening the position of research and development institutes involved in the development of technologies on the tea market, promoting pro-ecological policy and investing in modern technological developments in current crops).

\section{Alternative directions of tea cultivation}

Diversification of the crop losses is possible through the dissemination of other crop systems. In China, due to the popularity of pu-erh teas in over a dozen years, local authorities and smaller tea producers promote other methods of cultivation, both traditional and ecological. There are four systems for growing tea bushes (Karwowska, 2017). The most commonly used system in practice is plantation crops, discussed in the previous part of the study. The second system is forest crops. Tea bushes are integrated into the forest landscape. They can be created in two ways: by removing $2 / 3$ of shrubs from plantation crops and placing different types of trees and shrubs in their place, or through thinning of forest areas and supplementing them with Camelia shrubs. This way of cultivating is considered ecological, because human activity is limited only to the harvest of raw material, small crop trimming and fertilization with compost. Tea plants are allowed to reach a tree form, which diversifies the structure of the forest (Fig. 3). It has been shown that their size affects the 
development of epiphytic vegetation. The area looks natural, and it is a habitat for local animals and vegetation. The cultivation does not erode the soil. Plants have access to rich, adequately nourished and aerated soil. Thanks to the surroundings of other plants varying in height, tea plants are protected from intense climate change. The surrounding vegetation is a kind of "buffer". This solution was already piloted in 2011 in the Mangjing area of Yunnan. Even though farmers' earnings have diminished considerably, they have seen an opportunity to recreate the local ecosystem. This solution is now a new direction of change propagated by local authorities (Ahmed and Stepp, 2013b; Hung, 2013; Wang et al., 2017).

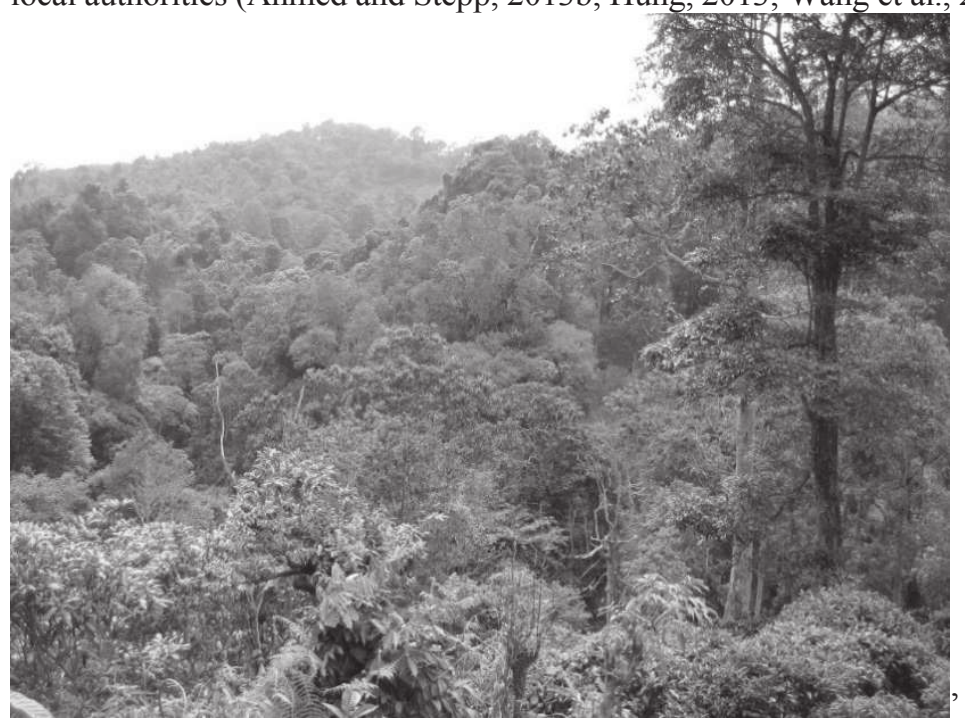

Fig. 3. Diversifed structure of forest crops

Source: https://www.sciencefriday.com/articles/seeing-the-forest-for-the-tea.

Also an ecological solution, but less popular than forest crops, are mixed arable fields. Like in forest crops, tea plants are mixed with native plants or other crops. In this version there is no large variation in the height of vegetation and tea bushes are constantly pruned and kept in shrubby form (Ahmed and Stepp, 2013b; Ahmed et al., 2013). The last type of crop is the so called "wild trees". They can be found deep in the jungle and are tea trees that are hundreds of years old and several meters high. Human interference is limited to leaf harvesting (Karwowska, 2017). Ahmed et al (2013) conducted research to differentiate the quality of raw material intended for tea production, obtained from various types of crops. In addition, they asked the owners of enterprises about economic aspects related to crop yields and sales profits. The greatest genetic diversity was observed among plants from mixed arable fields, and the smallest - from plantation crops. The method of cultivation carried out and genetic diversity have influenced the biochemical composition of the raw material. Differentiated crops had larger amounts of analyzed substances. The largest amount of material was collected in terrace cultivation, amounting to $64,000 \mathrm{~kg}$ from 1 ha. This was followed by mixed farmland $-18000 \mathrm{~kg} / \mathrm{ha}$, agro-forest crops $-13500 \mathrm{~kg} / \mathrm{ha}$ and forests $6000 \mathrm{~kg} / \mathrm{ha}$. The Chinese government introduced limits on the size of the harvest of leaves from "wild" trees, which is why the real possibility of obtaining this type of material is 
unknown. Plantation crops allow to achieve maximum crop yield, which does not translate into appropriately high profits. This kind of raw material is considered inferior in quality, so in 2010 for $1 \mathrm{~kg}$ of such leaves only \$3-8 was paid. For comparison, in the same year, $\$ 12.10$ USD was paid for raw material from mixed trees, \$157.26 USD from mixed arable fields, and the most, as much as $\$ 219.65$ for $1 \mathrm{~kg}$ of raw material, from forest crops (Ahmed et al., 2013). If local farmers decide to transform their crops and benefit from government subsidies, they will receive high-quality raw material thanks to ecological production methods. They will be able to employ a smaller number of collectors, which will reduce their costs slightly, which in the end should lead to increased earnings.

A great opportunity to increase the resistance of tea bushes to new climatic conditions is genomic selection and breeding programs. In the mid-nineteenth century, in China, India and South Africa, the selection of the best crops from the cultivations, their vegetative reproduction, and then the introduction of the hybrids into the crop system was introduced. This solution allowed to improve the efficiency of breeding plants, but also reduced their genetic diversity. The use of desirable agronomic traits has its justification for seedlings characterized by high genetic variation. However, large-scale multiplication of a small number of selected hybrids narrows down the gene pool and can lead, for example, to reduced resistance to stress. The successes of genetic improvement programs depend primarily on a good knowledge of the genetic background, the available natural diversity of the species and the solutions that will be introduced in an appropriate manner and at the right time (Hazra et al., 2018).

\section{Summary}

The plantation system of tea cultivation has a negative impact on the ecosystem, which after harvesting is very difficult and expensive to rebuild. China has been struggling with this problem for years, which is why ecological solutions, such as forest crops and mixed crops, are gradually being introduced in successive areas. The result of such changes is smaller amounts of raw material obtained for the production of tea. In addition, progressive climate change can lead to losses on tea plantations.

In order to avoid losses of raw material, and thus large fluctuations in prices, it is advisable to implement already available solutions and to continue to search for new innovative methods that increase the production of environmentally friendly raw materials.

Plantation crops allow to obtain the largest amounts of tea raw material. Therefore, it is necessary to keep some of the small-area terraced crops in areas characterized by the most stable climatic conditions. Forests and mixed arable land should have a larger share. In parallel, work should be carried out to find or create new varieties of the tea plant which are characterized by greater resistance to climate change, diseases and pests, as well as greater efficiency.

\section{Bibliography}

Ahmed, S., Peters, Ch.M., Chunlin, L., Meyer, R., Unachukwu, U., Litt, A., Kennelly, E., Stepp, J.R. (2013) Biodiversity and phytochemical quality in indigenous and state-supported tea management systems of Yunnan, China. Conservation Letters, 6, 28-36. 
Ahmed, S., Stepp, J.R. (2013a). Green Tea: The Plants, Processing, Manufacturing and Production. In: V.R. Preedy (ed.) Tea in Health and Disease Prevention (p. 19-31). London: Great Britain.

Ahmed, S., Stepp, J.R. (2013b). Pu-erh Tea: Botany, Production, and Chemistry. In: V.R. Preedy (ed.) Tea in Health and Disease Prevention (p. 59-71). London: Great Britain.

FAO (2015). World tea production and trade - Current and future development. Available 30 May 2018 from: http://www.fao.org/3/a-i4480e.pdf.

FAO (2016). Report of The Working Group on Climate Change of the FAO Intergovernmental Group on Tea. Available 2 July 2018 from: http://www.fao.org/3/a-i5743e.pdf.

FAO (2018a). Report of Intergovernmental Group of Tea, Current Market Situation and Medium Term Outlook. Available 5 October 2018 from: http://www.fao.org/economic/est/est-commodities/tea/tea-meetings/ tea23/en.

FAO (2018b). Report of Intergovernmental Group of Tea, Developing Futures and Swap Markets for Tea. Available 5 October 2018 from: http://www.fao.org/economic/est/est-commodities/tea/tea-meetings/ tea23/en.

FAO (2018c). Report of Intergovernmental Group of Tea, Emerging Trends in Tea Consumption: Informing a Generic Promotion Process. Available 5 October 2018 from: http://www.fao.org/economic/est/estcommodities/tea/tea-meetings/tea23/en.

Greenpeace (2015). Negatywny wpływ pestycydów na zdrowie. Rosnący problem (The negative impact of pesticides on health. A growing problem.) Available 10 October 2018 from: http://www.greenpeace.org/poland/PageFiles/671146/Raport_Wplyw_pestycydow_na_zdrowie.pdf.

Gurusubramanian, G., Rahman, A., Sarmah, M., Ray, S., Bora, S. (2008). Pesticide usage in tea ecosystem, their retrospects and alternative measure. Journal of Environmental Biology, 29 (6), 813-826.

GUS (2012). Rocznik Statystyki Międzynarodowej (International Statistical Yearbook). Warszawa.

GUS (2013a). Mały Rocznik Statystyczny Polski (Concise Statistical Yearbook of Poland). Warszawa.

GUS (2013b). Rocznik Statystyczny Rzeczpospolitej Polskiej (Statistical Yearbook of the Republic of Poland). Warszawa.

GUS (2014). Rocznik Statystyczny Rzeczpospolitej Polskiej (Statistical Yearbook of the Republic of Poland). Warszawa.

GUS (2015a). Mały Rocznik Statystyczny Polski (Concise Statistical Yearbook of Poland). Warszawa.

GUS (2015b). Rocznik Statystyczny Rzeczpospolitej Polskiej (Statistical Yearbook of the Republic of Poland). Warszawa.

GUS (2015c). Rocznik Statystyki Międzynarodowej (International Statistical Yearbook). Warszawa

GUS (2016). Rocznik Statystyczny Rzeczpospolitej Polskiej (Statistical Yearbook of the Republic of Poland). Warszawa.

GUS (2017a). Rocznik Statystyczny Rzeczpospolitej Polskiej (Statistical Yearbook of the Republic of Poland). Warszawa.

GUS (2017b). Rocznik Statystyki Międzynarodowej (International Statistical Yearbook). Warszawa.

GUS (2018). Mały Rocznik Statystyczny Polski (Concise Statistical Yearbook of Poland). Warszawa.

Hazra, A., Dasgupta, N., Sengupta, Ch., Das, S. (2018). Next generation crop improvement program: Progress and prospect in tea (Camellia sinensis (L.) O. Kuntze). Annals of Agrarian Science, 16, 128-135.

Hung, P.Y. (2013). Tea forest in the making: Tea production and the ambiguity of modernity on China's southwest frontier. Geoforum, 47, 178-188.

Karwowska, K. (2017). Typy upraw krzewu herbacianego w Chinach (Types of tea cultivation in China). In: Krättzig, M. (ed.) Badania i Rozwój Młodych Naukowców w Polsce - Agronomia i ochrona roślin (p. 103-108). Poznań.

Krzyżanowski, J. (thumaczenie) (2008). Herbata. Eliksir młodości, smaku i dobrego samopoczucia (Tea. Elixir of youth, taste and well-being). Warszawa, Świat Książki.

Kumar, R.S.S., Murugesan, S., Kottur, G., Gyamfi, D. (2013). Black Tea: The Plants, Processing/Manufacturing and Production. In: V.R. Preedy (ed.) Tea in Health and Disease Prevention (p. 41-57). London: Great Britain.

Mukhopadhyay, M., Mondal, T.K. (2017). Cultivation, Improvemental, and Environmental Impacts of Tea. Oxford Research Encyclopedia of Environmental Science. Available 28 September 2018 from: http://environmentalscience.oxfordre.com/view/10.1093/acrefore/9780199389414.001.0001/acrefore9780199389414-e-373.

RASFF. Available 10 October 2018 from: https://ec.europa.eu/food/safety/rasff_en.

Science Friday, Available 4 July 2018 from: https:/www.sciencefriday.com/wp-content/uploads/2017/03/IMG_ 2155.jpg. 
Toyb, N. (2016). Tea. An INFOCOMM Commodity Profiles. Selected paper prepared for presentation at the United Nations Conference on Trade and Development, New York and Geneva, 2016, 1-25.

Tomczyk, R. (2009). Zapiski o herbacie (Notes on tea). Warszawa: Wydawnictwo Fu Kang.

Wang, Q., Guan, W.B., Wong, M.H.G., Ranjitkar, S., Sun, W.N., Pan, Y., El-Kassaby, Y.A., Shen, L.X. (2017) Tree size predicts vascular epiphytic richness traditional cultivate tea plantations in Southwestern China. Global Ecology and Conservation, 10, 147-153.

Wachira, F.N., Karori, S., Kerio, L.C., Wanyoko, J.K. (2013). Cultivar Type and Antioxidant Potency of Tea Product. In: V.R. Preedy (ed.) Tea in Health and Disease Prevention (p. 91-102). London: Great Britain.

\section{For citation:}

Karwowska K., Skotnicka M., Śmiechowska M. (2019). Tea Production and its Forecasts, and the Possibility of Tea Cultivation in the Context of Environmental Requirements in China. Problems of World Agriculture, 19(1), STRONY; DOI: 10.22630/PRS.2019.19.1.17 